\title{
Supply of Aspect Tourism Effect on Travelling Interest
}

\author{
Herlin $^{\text {a }}$ Ida Ayu Made Er Meytha Gayatri ${ }^{b}$ \\ ${ }^{a, b}$ Universitas Dehasen Bengkulu, Indonesia \\ herlin_olin81@yahoo.com
}

\begin{abstract}
Purpose of this study aims to examine the effect supply aspect tourism on travelling interest to Tikus Island in Bengkulu Province. Supply aspect tourism consisting of attraction, accessible, amenities and ancillary. Sampling method in this study is accidental sampling with 240 respondents. Data collection method in this study uses quantitative data which is carried out by distributing questionnaires. Multiple regression analysis applied to test the hypotheses using SPSS application. Findings showed that attraction and accessible have positive effect on travelling interest. Meanwhile, amenities and ancillary do not affect travelling interest. The supply of aspect tourism in Tikus Island can contribute to the Regional Original Income (PAD) of Bengkulu Province, the local government of Bengkulu should be able to pay more attention based on this findings.
\end{abstract}

Article Info

- Received : October 25, 2019

- Revised : January 3, 2020

- Published : January 19, 2020

- No. Pages : 100-105

- DOI : 10.33019/ijbe.v4i1.249

- JEL : L83

- Keywords : supply aspect tourism, attraction, accessibility, amenities, ancillary, travelling interest, Tikus island, Bengkulu province

\section{Introduction}

Indonesia is one of the countries that has become a tourist destination, so it is not surprising that many foreign tourists who come on vacation to Indonesia, which has an impact on increasing the regional income sector in the field of tourism. Contribution of the tourism sector to the revenues of the regional government, both directly and indirectly, makes the economy around tourism places better, such as the absorption of labor and the creation of tourism-related businesses such as accommodation, restaurants, clubs, taxis and souvenir craft businesses. (Main, 2016). Regional Original Income from tourism sector will increase if many visitors come to travel. So, to attract interest in travelling to a tourist attraction, tourism supplies are needed that offer interesting things from managed tourism objects such as various attractions and facilities. Attractions that offer attraction, complete facilities and satisfying services will be visited by many tourists. According to Utama (2016) as for factors that can affect tourism offerings (tourism supply) are tourist attractions, hotels or accommodations, immigration services, restaurants, shopping centres and transportation. With a growing number of attractions when visiting tourist destinations, tourists expect a positive experience so that supply is one of the determining factors in giving a positive impression by Payangan, Sahabuddin, \& Girikallo (2017). 
Bengkulu Province is one of the provinces located in the western part of Sumatera Island at latitude 2016 '3031 latitudes and longitude 10101 '103041 'BT. Bengkulu Province is a mountainous area of Bukit Barisan and extends from the border of West Sumatra Province to the border of Lampung Province along approximately $567 \mathrm{~km}$ with an area of $151.70 \mathrm{~km} 2$, located on the West coast of Sumatra Island with a beach area of around $525 \mathrm{~km}$ (BPS Bengkulu, 2016). Tikus Island is a small coral island measuring about $0.8 \mathrm{Ha}$ located west of Bengkulu City. With a distance of about $10 \mathrm{KM}$ from the city centre, Tikus Island is surrounded by coral and rich in biological resources and has been designated as a tourism forest (SK Menhut No. 602/Kpts-II/1991). The Tikus island of Bengkulu Province is one of the attractions included in the potential category developed by the Bengkulu Province Tourism Service visiting visit the wonderful Bengkulu. Previous project by Herlin and team in 2018, is proof that the Tikus island tourism development strategy that can be applied is the development in the transportation sector and supporting facilities in the Tikus island tourist area. Application of appropriate strategies in the development of Tikus island tourism and the attractiveness of Tikus islands that are not owned by other tourist attractions in Bengkulu province make many visitors who are interested in travelling to the Tikus Island, thus increasing the Bengkulu Province's Original Revenue. With so interesting attractions in Tikus Island, this study will explore the effect of supply aspect tourism on travelling interest.

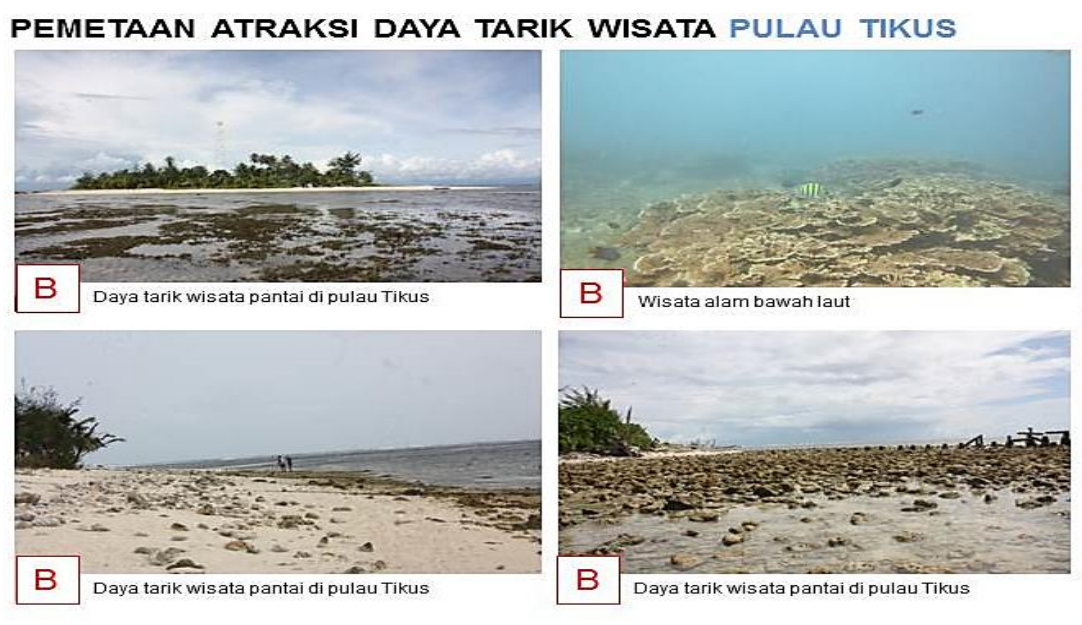

Source: Bengkulu Province Tourism Office
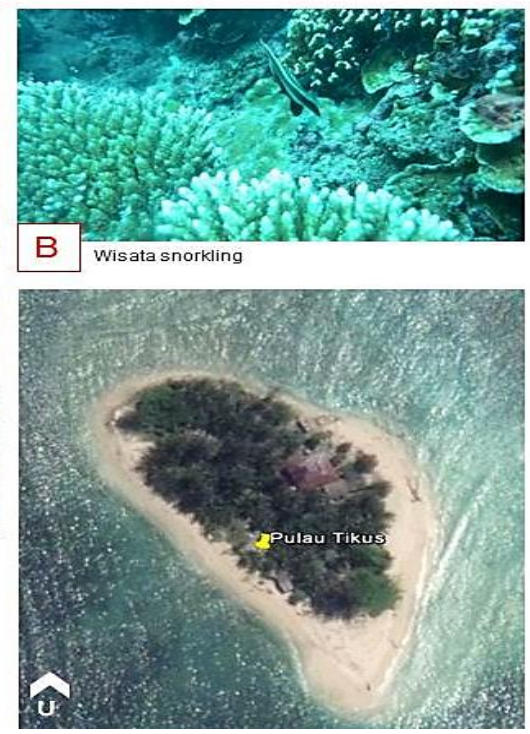

Figure 1. Tikus Island

\section{Literature Review}

Medlik (2016) defines tourism as a travel activity carried out temporarily from the original place of residence to the destination area with the excuse not to settle or earn a living but only to have fun, fulfil curiosity, spend leisure time or holiday time and destination-other purposes. According to the Republic of Indonesia's Law No. 9 Year 1990 concerning tourism, consists of (1) tourism services, (2) business of tourist objects and attractions, (3) tourism facilities business. According to Republic of Indonesia's Law No. 9 of 1990 concerning tourism (2016), tourism business consists of (1) tourism services, (2) business of tourist objects and attractions, (3) tourism facilities business. Utama (2016) there are 4 (four) indicators that must be considered in tourism offerings:

a. Attraction, Regional tourist destinations to attract tourists must have an attraction, both the attraction of nature and society and culture. 
b. Accessible, Transportation is intended so that domestic and foreign tourists can easily reach the destination to tourist attractions.

c. Amenities, facilities are indeed one of the requirements for tourist destinations to be able to stay longer in tourist destinations.

d. Ancillary, the existence of tourist tourism agencies will increasingly visit and search for tourist destinations if the area tourists can feel security (protection of tourism) and protected.

Theory of interest in visiting or travelling in research conducted by Albarq (2014), Jalivand \& Samiei (2012) which equates that tourists visiting interests are the same as the interests of consumer purchases. Kotler and Keller (2009), two external factors influence someone's buying interest. First, the attitude of others, in this case, the attitude of others who influence buying interest depends on two things. Second, situations that are not inspired, are situations that suddenly appear and can indirectly change consumers' buying interest. Therefore, the hypothesis proposed in this study is as follows:

H1: Attraction has a significant effect on travelling interest.

$\mathrm{H} 2$ : Accessible has a significant effect on travelling interest.

H3: Amenities has a significant effect on travelling interest.

H4: Ancillary has a significant effect on travelling interest.

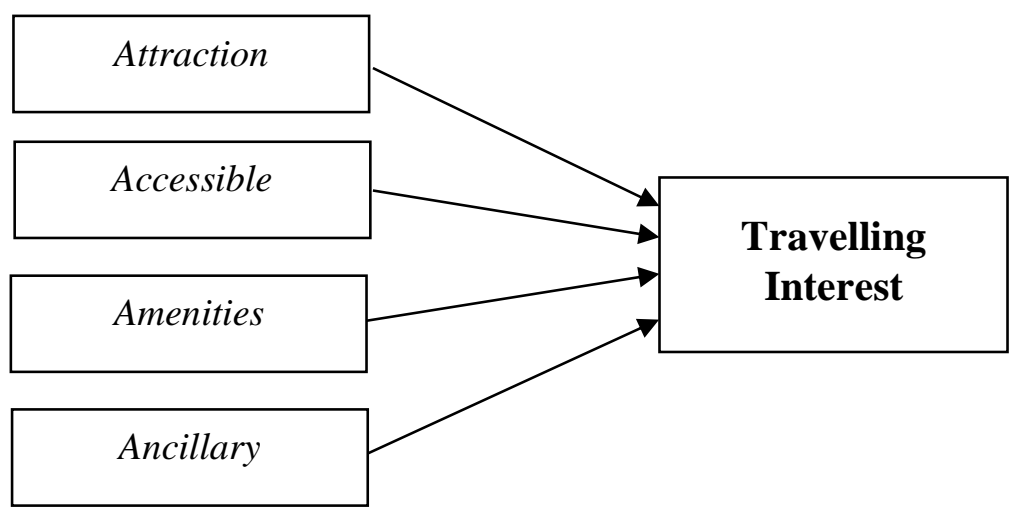

Figure 1. Conceptual Framework

\section{Research Methods}

Tapri Padri Beach and Long Beach in Tikus Island selected as the area of this research, which located in Bengkulu City. This type of research is explanatory research. Sampling method in this study using accidental sampling with 240 respondent. Data collection method use quantitative data which is carried out by distributing questionnaires with Likert scale (1 to 5) as of measurement scale of variables. Multiple regression analysis applied to process data, which is used to measure the influence of independent variables; attraction (X1), accessible (X2), amenities (X3) and ancillary (X4) with travel interest (Y) as dependent variable. Regression Equation can be shown below:

Travelling Interest $=\mathrm{a}+\mathrm{b}_{1}$ Attraction $+\mathrm{b}_{2}$ Accessible $+\mathrm{b}_{3}$ Amenities $+\mathrm{b}_{4}$ Ancillary $+\mathrm{e}$

Where:

$\mathrm{a}=$ constants

$\mathrm{b}=$ coefficient parameter

$\mathrm{e}=$ error 
Validity and reliability tests were conducted to test research instrument, where the question indicator can be said to be valid if the total item correlation value is $>0.5$ and reliable if the Cronbach's alpha value $>0.6$ or 0.7 (Hair et al., 2014). Normality and multicollinearity conducted before processing collected data by using SPSS application. Data said to be Normal, if the Kolmogorov-Smirnov statistic value (K-S) $>\alpha=0.05$ (Ghozali, 2013). A good regression model should not correlate with independent variables. If the tolerance value and Variance Inflation Factor (VIF) $\leq 0.10$ or equal to the value of $\geq 10$, then there is no multicollinearity in the regression model seen from the value of tolerance (Ghozali, 2013).

\section{Results}

All question items have a total item correlation value of more than 0.5 , so it can be said that all items are valid. Reliability testing on variables Attraction has Cronbach's Alpha value $(0,847)$, Accessible $(0,804)$, Amenities $(0,635)$, Ancillary $(0,612)$ and Travel Interests $(0,736)$. From Cronbach alpha values above, it can be said that all variables are reliable. Based on the result shows that the number of respondents (n) in this study is 240 and the Kolmogorov-Smirnov value is 1.170 , where this value is greater than the 0.05 significance value, meaning that the data in this study were normally distributed. Based on Table 1, shows the variables used in this study are Attraction, Accessible, Amenities, and Ancillary obtaining Tolerance $>0.1$ and Variant Inflation Factor $(\mathrm{VIF})<10$, so it can be concluded that the regression model used is free from multicollinearity or there is no multicollinearity between independent variable.

Table 1. Multicollinearity Test

\begin{tabular}{ccc}
\hline \multirow{2}{*}{ Variable } & \multicolumn{2}{c}{ Multicollinearity } \\
\cline { 2 - 3 } & Tolerance & VIP \\
\hline Attraction & 0,929 & 1,076 \\
\hline Accessible & 0,806 & 1,241 \\
\hline Amenities & 0,716 & 1,397 \\
\hline Ancillary & 0,771 & 1,298 \\
\hline
\end{tabular}

Source: SPSS Output

Based on the results above, showing the data in this study meet the requirements to proceed to regression mode to do further hypothesis testing, with the regression model in this study.

Table 2. Regression Result

\begin{tabular}{|c|c|c|c|c|c|c|}
\hline \multicolumn{7}{|c|}{ Coefficients $^{\mathbf{a}}$} \\
\hline \multirow[b]{2}{*}{ Model } & & \multicolumn{2}{|c|}{ Unstandardized Coefficients } & \multirow{2}{*}{$\frac{\text { Standardized Coefficients }}{\text { Beta }}$} & \multirow[b]{2}{*}{$\mathrm{t}$} & \multirow[b]{2}{*}{ Sig. } \\
\hline & & B & Std. Error & & & \\
\hline \multirow[t]{5}{*}{1} & (Constant) & 118.501 & 37.480 & & 3.162 & .002 \\
\hline & Attraction & -4.201 & 1.420 & -.182 & -2.958 & .003 \\
\hline & Accessible & -.647 & 1.340 & -.032 & -.482 & .630 \\
\hline & Amenities & 3.075 & 2.005 & .107 & 1.533 & .127 \\
\hline & Ancillary & 8.453 & 1.630 & .350 & 5.187 & .000 \\
\hline
\end{tabular}

a. Dependent Variable: travelling_interest

Source: SPSS Output

Regression equation based on result:

Interest to travel $=118,501-4,201 \mathrm{X}_{1}-0,647 \mathrm{X}_{2}+3,075 \mathrm{X}_{3}+8,453 \mathrm{X}_{4}+\mathrm{e}$ 
Table 3. Hypothesis Test Result (t-test)

\begin{tabular}{cccccc}
\hline IV & DV & Coefficient Value & $\mathrm{t}_{\text {count }}$ & Sig & Information \\
\hline Attraction & $\begin{array}{c}\text { Travelling } \\
\text { Interest }\end{array}$ & 118,501 & 3,162 & 0,002 & Hypothesis accepted \\
\hline Accessible & $\begin{array}{c}\text { Travelling } \\
\text { Interest }\end{array}$ & $-4,201$ & $-2,958$ & 0,003 & Hypothesis accepted \\
\hline Amenities & $\begin{array}{c}\text { Travelling } \\
\text { Interest }\end{array}$ & $-0,647$ & $-0,482$ & 0,630 & Hypothesis rejected \\
\hline Ancillary & $\begin{array}{c}\text { Travelling } \\
\text { Interest }\end{array}$ & 3,075 & 1,533 & 0,127 & Hypothesis rejected \\
\hline \multicolumn{2}{c}{$\mathrm{R}^{2}=0,417 ;$ Adj $\mathrm{R}^{2}=0,160 ; \mathrm{F}=12,385 ; \mathrm{Sig}=0,00$} & \\
\hline
\end{tabular}

IV: Independent variable; DV: Dependent variable

Source: SPSS output

Based on Table 3 above, the coefficient of determination (Adjusted $\mathrm{R}^{2}$ ) is 0.160 or $16 \%$, which means that attraction, accessible and ancillary can explain their influence on interest in travel, while the rest $84 \%$ influenced by other factors outside the model. Value of F-count is 12.385 with a significant value of 0.000 which means it is smaller than $0.05 \%$ (Model Fit). The testing attraction on travelling interest obtained 118,501 with a significance level of $0.002(<0.05)$, this proves that attraction affects travelling interest, so the first hypothesis (H1) is accepted. Tests of accessible towards travelling interest obtained regression coefficient value is negative at -4.201 with a significance level of $0.003(<0.05)$. Regression coefficient values although has negative results, thus proving that accessible influences travelling interest with the significant value, so the second hypothesis ( $\mathrm{H} 2)$ is accepted. Testing of amenities on travelling interest has negative coefficient at -0.482 with a significance level of $0.630(>0.05)$. It proves that amenities do not affect travelling interest, so the third hypothesis (H3) is rejected. The ancillary test on the travelling interest obtained 1.533 with a significance level of 0.127 (>0.05), this proves that ancillary does not affect travelling interest, so the fourth hypothesis (H4) is rejected.

\section{Conclusion}

\section{Conclusion}

Attraction influences travelling interest, indicate that attraction influences the demand for trips to Tikus Island of Bengkulu Province. Meanwhile accessible has significant value that indicates transportation access is one of the important factors for tourist's interest in visiting the island. Better existing accessibility for travelling will increase visitors who will travel to the island. Facilities in Tikus Island are not able to attract tourists to visit, additional and renewal of facilities required by the local government are needed. Moreover, Ancillary (institutional) should play an important role to attract tourists to travel interest in promoting Tikus Island, but not too significant. To attract interest in a trip to the Tikus Island, it is better to have better public facilities such as prayer rooms and toilets, the presence of businesses, security posts and hazard warning signs for dangerous places. Moreover, there should be a decent lodging place for visitors if tourist wants to spend the night in Tikus Island. So that the supply of aspect tourism in Tikus Island can contribute to the Regional Original Income (PAD) of Bengkulu Province, the local government of Bengkulu should be able to pay more attention based on this research result.

\section{References}

1) Albarq, A. N. (2014). Measuring the impacts of online word-of-mouth on tourists' attitude and intentions to visit Jordan: An empirical study. International Business Research, 7(1), 14. 
2) BPS Bengkulu (Statistics Indonesia). (2016). Provinsi Bengkulu Dalam Angka. Provinsi Bengkulu

3) Dinas Pariwisata Bengkulu. (n.d.). Wonderfull Bengkulu 2020: Dinas Pariwisata Provinsi Bengkulu. Retrieved May 17, 2019, from https://pariwisata.bengkuluprov.go.id/

4) Ghozali, I. (2013). Aplikasi Analisis Multivariate dengan Program IBM SPSS 21 Update PLS. Edisi Ketujuh. Penerbit Universitas Diponegoro. Semarang.

5) Hair Jr, J., Sarstedt, M., Hopkins, L., \& G. Kuppelwieser, V. (2014). Partial least squares structural equation modelling (PLS-SEM) An emerging tool in business research. European Business Review, 26(2), 106-121.

6) Indonesia's Law No. 9 Year 1990 Concerning Tourism.

7) Jalilvand, M. R., \& Samiei, N. (2012). The effect of word of mouth on inbound tourists' decision for travelling to Islamic destinations (the case of Isfahan as a tourist destination in Iran). Journal of Islamic Marketing.

8) Kotler, P., \& Keller, K. L. (2009). Manajemen Pemasaran Edisi 13. Jakarta: Erlangga.

9) Medlik, S. (Ed.). (2016). Managing tourism. Elsevier.

10) Payangan, O. R., Sahabuddin, R., \& S Girikallo, A. (2017). Mediation Effect of Marketing Mix Strategy on Supply and Demand towards Marketing Performance. Journal of Environmental Management and Tourism, 8(1 (17)), 223-231.

11) Sayangbatti, D. P., \& Baiquni, M. (2013). Motivasi dan Persepsi Wisatawan tentang Daya tarik Destinasi terhadap minat Kunjungan Kembali di kota wisata Batu. Jurnal Nasional Pariwisata, 5(2), 126-136.

12) Utama, I. G. B. R. (2016). Pemasaran Pariwisata. Penerbit Andi. 